\title{
Problem Doktrin Rasisme Etnis China sebagai WNI (Status Kewarganegaraan Etnis China)
}

\author{
Sidik Sunaryo, Shinta Ayu Purnamawati \\ Fakultas Hukum Universitas Muhammadiyah Malang \\ sidik_sunaryo@yahoo.co.id
}

Submit: 16-05-2020; Review: 16-05-2020; Terbit: 24-06-2020

\begin{abstract}
The law on racial regulation in Indonesia cannot be seen from good and bad perspectives, but the law on racial regulation in Indonesia must be seen from the perspective of right and wrong. Between one and another provisions are still contradictory which is the cause of the constitutional problem of legal irregularity that regulates the guarantee of rights and obligations for racial and ethnic Chinese citizens in line with the original Indonesian citizens. This paper studied about the form of legal irregularities for race (ethnicity) of China in the constitution in Indonesia. Its to analyze and provide solutions as a result of legal irregularities in the Indonesian constitution for Chinese ethnic. The methods uses normative juridical methods, namely analyzing positive legal material to answer problems in research using positive law and law as indicators. The results of the study show that there are distinctions between original and non-original Indonesian citizens, which is evidence of the problem of legal irregularities that justifies racism in Indonesia. Its cause differences in the treatment of the State administrators to non-native Indonesian citizens of race and ethnic China in the social, cultural, religious, demographic and immigration fields.
\end{abstract}

\section{Keywords: Constitution, Citizenship Status, Legal Irregularities.}

\begin{abstract}
Abstrak
Tulisan ini menjelaskan problem doktrin hukum formal Negara (Konstitusi) yang mengatur tentang hubungan antara Ras yang ada di Indonesia. Hukum tentang pengaturan ras di Indonesia, tidak bisa dilihat dari perspektif baik dan buruk saja, tetapi pengaturan ras di Indonesia harus dilihat dalam perspektif benar dan salah. Antara ketentuan satu dengan yang lainnya masih saling bertentangan yang menjadi penyebab problem konstitusional, ketidakteraturan hukum jaminan hak dan kewajiban bagi WNI ras dan etnis China secara sejajar dengan WNI asli. Permasalahan yang menjadi kajian dalam penelitian ini adalah menganalisa wujud ketidakteraturan hukum bagi ras (Keturunan atau Etnis) China dalam konstitusi di Indonesia. Tulisan ini bertujuan untuk menganalisa dan memberikan solusi akibat adanya ketidakteraturan hukum dalam konstitusi Indonesia bagi ras Keturunan atau Etnis China di Indonesia. Penelitian ini menggunakan metode yuridis normative, yaitu menganalisis bahan hukum positif untuk menjawab masalah penelitian dengan menggunakan Undang - undang dan hukum positif sebagai indikator. Hasil penelitian menunjukkan adanya pembedaan
\end{abstract}


WNI asli dan tidak asli menjadi bukti problem ketidakteraturan hukum yang menjustifikasi Rasisme di Indonesia. Hal ini mengakibatkan perbedaan perlakuan dari penyelenggara Negara terhadap WNI tidak asli dari ras dan etnis China dalam bidang sosial, budaya, agama, kependudukan dan keimigrasian.

\section{Kata Kunci: Konstitusi, Status Kewarganegaraan, Ketidakteraturan Hukum.}

\section{Pendahuluan}

Secara empiris bangsa Indonesia memiliki ciri dan sifat aneka ragam budaya, adat, keyakinan, agama, suku, ras, keturunan, bahasa, dan lain-lain. Keanekaragaman tersebut kemudian oleh pendiri Negara disederhanakan dengan istilah Bhineka Tunggal Ika, yang arti lepasnya berbeda-beda tetapi tetap satu. Arti lepas ini juga berbeda apabila diartikan kesatuan yang berbeda-beda, demikian juga akan mempunyai makna lain pula apabila diartikan kesatuan yang berbeda. Keanekaragaman ini harus menjadi kekayaan dan bukan hanya sekedar beda yang satu. Tulisan ini mencoba menjelaskan problem doktrin hukum formal Negara (Konstitusi) yang mengatur tentang hubungan antara Ras (Keturunan atau Etnik, selanjutnya dalam tulisan ini disebut dengan ras) yang ada di Indonesia. Hukum tentang pengaturan ras di Indonesia, tidak bisa dilihat dari perspektif baik dan buruk saja, tetapi hukum pengaturan ras di Indonesia harus dilihat dalam perspektif benar dan salah. Sebab pengaturan tentang Ras di Indonesia bersumber dari keanekaragaman ras di Indonesia. Bhineka Tunggal Ika adalah dogma pembenaran dari keanekaragaman tersebut. Indonesia, memiliki lebih kurang 13.700 pulau-pulau dengan ribuan suku, ras dan ada sekitar 1200an bahasa yang dipergunakan oleh suku dan ras tersebut. Kemudian Negara menyatukan dengan satu nusa, satu bangsa dan satu bahasa (Sumpah Pemuda, 1928).

Secara historis, keanekaragaman tersebut disamping merupakan kekuatan juga seringkali menjadi ancaman dalam hubungan terkait dengan masalah sosial, agama, ekonomi, budaya, adat istiadat, politik, hukum, pertahanan, dan keamanan. Namun, seringkali persoalan perselisihan antara ras 
yang terjadi adalah perselisihan yang disebabkan oleh masalah ekonomi, kemudian selalu dikaitkan dengan masalah budaya, adat istiadat, agama, sosial, politik yang mengakibatkan terganggunya keamanan dan pertahanan negara.

Ras China selalu menarik untuk dibicarakan, karena sampai hari ini masih terdapat anggapan bahwa Ras China belum sepenuhnya diterima menjadi bagian integral dari keanekaragaman yang membentuk Bhineka Tunggal Ika di Indonesia. Ras China (Jawa Pos, 2011), sudah mendiami wilayah nusantara jauh sebelum Republik Indonesia merdeka sebagai Negara.

Ras China secara umum di Indonesia secara ekonomi lebih mapan dibandingkan dengan ras yang lain. Hanya di beberapa tempat seperti di Padang, di Makasar (Bugis), Ras China secara ekonomi tidak kelihatan menonjol dari pribumi. Industri, pabrik, perbankan, plaza, supermarket, perhotelan, pariwisata, di berbagai wilayah di Indonesia, lebih banyak dimiliki atau dikuasai oleh Ras China. Hukum Negara memang memberikan kebebasan bagi semua WNI untuk usaha di bidang ekonomi tanpa terkecuali. Secara empiris, bidang usaha ekonomi ini seringkali menjadi salah satu penyebab timbulnya perselisihan atau sengketa antara ras China dengan ras pribumi. Konflik horizontal antara ras tersebut sebenarnya bukan masalah kebencian antara ras tersebut dalam bidang ekonomi, dan lain-lain, tetapi lebih disebabkan oleh kegagalan Negara dalam mensejahterakan rakyatnya.

Konflik horizontal antara ras menjadi alasan pembenar tindakan represif Negara terhadap pelaku konflik, sekaligus keberhasilan Negara dalam menutupi keculasannya untuk lepas terhadap tanggungjawab mensejahterahkan rakyatnya secara konstitusional. Dalam konteks demikian Konstitusi dan hukum formal, Negara tidak mampu memberikan pembenaran problem yang menimbulkan konflik horizontal antar etnis dalam bingkai Bhinneka Tunggal Ika. Hukum dan Konstitusi juga agak sulit untuk dipaksa hadir dalam membela salah satu etnis dalam kerusuhan dan peristiwa di atas. Sulitnya membela Etnis China itulah yang paling mudah untuk dilekatkan untuk 
sekedar lepas tanggung jawab dalam problem kegagalan penyelenggara Negara dalam mewujudkan tujuan dibentuknya Negara dalam Konstitusi, yakni, mencerdaskan kehidupan bangsa, memajukan kesejahteraan umum, melindungi segenap bangsa, perdamaian abadi dan keadilan sosial.

Persoalan dengan keanekaragaman bangsa yang dibingkai dalam dogma Bhineka Tunggal Ika, apakah cita-cita kemerdekaan tersebut sudah diwujudkan dalam usia kemerdekaan Indonesia yang memasuki usia 75 tahun ini. Dalam bidang ekonomi, secara empiris masih terdapat persoalan mendasar yang bersumber dari kecurigaan ras pribumi terhadap penguasa Negara, yang masih dipandang membedakan perlakuan kebijakan dengan ras China. Di sisi lain, ras China yang kehadirannya di bumi nusantara ini jauh sebelum Republik Indonesia ini merdeka menjadi bangsa berdaulat, juga mempunyai peran yang sama dalam 'memerdekakan' bangsa ini, tetapi masih merasakan ketidakadilan perlakuan hukum dalam berbagai bidang. Kemakmuran secara simbolis yang dimiliki antara ras pribumi dengan ras China, masih dipandang tidak adil oleh ras pribumi. Sementara di sisi lain, kesulitan dalam bidang kependudukan dan imigrasi masih dirasakan sebagai sebuah "Cap" ketidakadilan yang masih membedakan perlakuan ras China dengan ras pribumi sebagai bagian integral bangsa dalam bingkai Negara Kesatuan Republik Indonesia.

Furnivall selanjutnya menjelaskan bahwa orang - orang Belanda, orang - orang Tionghoa, orang - orang indonesia Pribumi, melalui agama, kebudayaan, dan bahasa mereka masing - masing, mempertahankan atau memelihara pola pikiran, atau cara hidup masingmasing. Oleh karena itu, masyarakat Indonesia secara keseluruhan tidak memiliki kemauan bersama (common will) (Nurhadiantomo, 2004:34).

Dari paparan di atas, permasalahan yang menjadi kajian dalam penelitian ini adalah: bagaimanakah wujud ketidakteraturan hukum bagi ras (Keturunan atau Etnis) China Dalam Konstitusi Di Indonesia. Adapun tujuan penelitian ini adalah untuk 
menganalisis dan memberikan solusi akibat adanya ketidakteraturan hukum dalam konstitusi Indonesia bagi ras (keturunan atau etnis) China di Indonesia.

\section{Metode Penelitian}

Dalam penelitian ini digunakan metode yuridis normatif yaitu menganalisis bahan hukum positif untuk menjawab masalah dalam penelitian dengan menggunakan Undang - undang dan hukum positif sebagai indikator. Terkait permasalahan status kewarganegaraan etnis china, bahan hukum yang digunakan sebagai indikator dan dasar analisa yuridis adalah UUD 1945 serta UndangUndang Nomor 3 Tahun 1945 Tentang Kewarganegaraan, UndangUndang Nomor 62 Tahun 1958 Tentang Kewarganegaraan, UndangUndang Nomor 12 Tahun 2006 Tentang Kewarganegaraan, UndangUndang Nomor 23 Tahun 2006 Tentang Administrasi

Kependudukan, dan UndangUndang Nomor 40 Tahun 2008 Tentang Penghapusan Diskriminasi Ras dan Etnis.

\section{Hasil dan Pembahasan}

\section{Justifikasi Ketidakteraturan Hukum Bagi Ras China Dalam Konstitusi Di Indonesia.}

Keanekaragaman ras sebenarnya sudah diakui keberadaannya pada kekuasaan kolonial Belanda. Peraturan Ketatanegaraan kolonial Belanda (Indische Staatsregeling-I.S. tahun 1937), dalam ketentuan pasal 16 a3 ayat 1 , membagi 3 golongan pendudukan yang diakui di wilayah Hindia Belanda, yakni : Golongan Eropah (Belanda, Orang Eropah lainnya, Jepang yang kaitannya dengan perdagangan, Amerika, Australia, Rusia, Afrika Selatan beserta keturunannya); Golongan Timur Asing (China/Tionghoa, Arab, India, Pakistan, Mesir); Golongan Bumiputera (orang Indonesia Asli beserta keturunannya). Menurut Hindia Belanda, penggolongan penduduk tersebut akan berimplikasi pada hukum yang dibuat dan diberlakukan. Bagi Golongan Eropah berlaku hukum Eropah asalnya, bagi Golongan Timur Asing China berlaku Stb. 1924 Nomor 557, yang menegaskan berlaku hukum Barat/ Eropah kecuali Pencatatan Sipil, Cara Perkawinan, Adopsi, Kongsi/Firma berlaku hukum 
Eropah. Sedangkan Timur Asing bukan China berlaku hukum Barat/ Eropah, kecuali hukum kekeluargaan, hukum waris. Sedangkan Golongan Bumiputera berlaku Hukum Adat, sepanjang tidak bertentangan dengan hukum Barat/ Eropa.

Dalam hukum yang berlaku pada jaman Hindia Belanda, memang tidak memberikan pembatasan pilihan hak warga Negara khususnya Timur Asing/Ras China. Kehadiran Ras China pada jaman Hindia Belanda lebih banyak bertujuan untuk berdagang. Namun, dalam perkembangannya keturunan yang berasal dari ras China berkembang dengan cepat melalui hukum perkawinan yang 'membebaskan' ras China untuk melakukan perkawinan antar ras China. Dengan model perkawinan demikian, perkembangan jumlah penduduk Timur Asing China semakin hari semakin cepat bertambah. Apalagi ditambah kebijakan pemerintah Hindia Belanda yang memberikan kebebasan dalam bidang perdagangan termasuk di dalamnya hukum kepemilikan tanah yang sangat kuat dan bebas bagi pemiliknya untuk menggunakan dan memanfaatkannya (Pasal 580 BW).

Setelah kemerdekaan tanggal 17 Agustus 1945, era pengaturan rezim hukum berganti dari hukum kolonial kedalam rezim hukum Republik Indonesia.

Dalam pasal 26 UUD 1945 (sebelum amandemen) ditegaskan bahwa :

(1) Yang menjadi warga negara ialah orang-orang Bangsa Indonesia Asli dan orang-orang bangsa lain yang disahkan dengan Undangundang sebagai warganegara; (2). Syarat-syarat yang mengenai kewarganegaraan ditetapkan dengan Undang-undang. Dalam penjelasannya dinyatakan bahwa orang-orang bangsa lain, misalnya orang peranakan Belanda, peranakan Tionghoa, dan peranakan Arab yang bertempat kedudukan di Indonesia, mengakui Indonesia sebagai tanah airnya dan bersikap setia kepada Negara Republik Indonesia dapat menjadi warga Negara.

Dalam pasal 6 UUD 1945 (sebelum amandemen) ditegaskan bahwa : Presiden ialah orang Indonesia Asli.

Penegasan kata ASLI tersebut membawa konsekuensi yuridis konstitusional, bahwa warga Negara yang tidak Asli hanya memiliki hak dalam bidang politik secara pasip, dan tidak memiliki hak politik secara 
aktif. Artinya ras China yang merupakan warga Negara Indonesia yang tidak Asli hanya mempunyai hak memilih dan tidak mempunyai hak dipilih dalam bidang politik. Ketentuan berikutnya adalah pasal 27, 28, 29, 30, 31, 32, 33, memberikan penegasan tentang hak dan kewajiban warga Negara tanpa membedakan keturunan asli atau tidak asli.

Pasal 27 UUD 1945 (sebelum amandemen) : (1) segala warga Negara bersamaan kedudukannya di dalam hukum dan pemerintahan dan wajib menjunjung hukum dan pemerintahan itu dengan tidak ada kecualinya, (2) tiap-tiap warga Negara berhak atas pekerjaan dan penghidupan yang layak bagi kemanusiaan.

Ras keturunan China merasakan sebagai warga Negara yang tidak sama kedudukannya di dalam hukum dan pemerintahan. Sebab era orde baru khususnya, semua penyelenggara Negara harus bersih diri dan atau bersih lingkungan. Screening merupakan media yang dijadikan alat ukur penguasa orde baru untuk menyaring jangan sampai ada warga Negara yang tidak bersih lingkungan dan dirinya dari PKI menyelundup menjadi penyelenggara Negara dalam semua bidang dan tingkatan. China (secara sentimental) dalam pandangan politik saat itu (masih dikesankan) dikelompokkan sebagai bagian dari bangsa dengan ideologi yang dekat dengan komunis yang harus diperangi. Sementara orde baru sangat percaya pada ideologi kapital yang dibungkus dalam demokrasi (ekonomi) Pancasila. Negara-negara Barat seperti Amerika Serikat dan Sekutunya menjadi Saudara Tua sebagai tempat keluh kesah dan Dewa Penyelamat pada hampir semua bentuk kebijakan dan hukum yang dibuat pada era orde baru tersebut.

Pasal $28:$ kemerdekaan berserikat dan berkumpul, mengeluarkan pikiran dengan lisan dan tulisan dan sebagainya ditetapkan dengan undang-undang.

Dengan ketentuan pasal 28 inipun tidak serta merta ras keturunan China dengan bebas berserikat, berkumpul, kecuali dalam bidang usaha perdagangan dan ekonomi. Ras keturunan China juga tidak bebas mengeluarkan pikiran dengan lisan dan dengan tulisan, sebab faktanya khususnya selama pemerintahan orde baru, tidak ada partai khusus China dan oleh 
karenanya tidak mungkin ras keturunan China bisa dengan bebas mengeluarkan pikiran dan pendapatnya dalam bentuk kebijakan dan hukum formal yang dibuat oleh legislatif dalam DPR dan DPRD. Kalaupun ada Etnis China yang ikut memberikan pendapatnya dalam mempengaruhi kebijakan dan hukum Negara, dilakukan secara perorangan atau melalui usaha mereka.

Pasal 29 (1) Negara berdasar atas Ketuhanan Yang Maha Esa, (2) Negara menjamin kemerdekaan tiaptiap penduduk untuk memeluk agamanya masing-masing dan untuk beribadat menurut agamanya dan kepercayaannya itu.

$\begin{array}{ccr}\text { Dari } & \text { ketentuan } & \text { "tiap-tiap } \\ \text { penduduk" } & \text { tersebut } & \text { dalam } \\ \text { prakteknya } & \text { berimplikasi } & \text { bagi }\end{array}$
keturunan China khususnya. Sebab apabila belum bisa menunjukkan bukti hukum (KTP) sebagai penduduk Indonesia menurut Undang-undang Kewarganegaraan yang berlaku, maka mereka juga tidak mendapat jaminan kemerdekaan untuk memeluk agama mereka. Untuk urusan kependudukan sebagaimana yang diatur dalam Undang-undang Kewarganegaraan masih membedakan perlakuan hak antara WNI asli dan WNI keturunan atau tidak asli (dalam hal ini China). Kesulitan mengurus status kewarganegaraan yang dialami ras keturunan China di Indonesia, tidak saja dalam tataran substansi Undangundang tetapi dalam tataran praktek menunjukkan betapa proses diskriminasi yang dilakukan oleh Negara semakin menemukan bentuknya. Hal ini misalnya selama era orde lama dan orde baru keturunan China yang beragama Konghucu tidak mendapat jaminan kebebasan menjalankan agamanya karena Konghucu tidak diakui sebagai agama resmi di Indonesia. Baru era Habibie, Gus Dur, dan Megawati, Konghucu resmi diakui menjadi agama di Indonesia.

Pasal 30 (1) :Tiap-tiap warga Negara berhak dan wajib ikut serta dalam usaha pembelaan Negara, (2) syarat-syarat tentang pembelaan diatur dengan undang-undang.

Ketentuan Pasal 30 ini juga tidak bisa dirasakan oleh ras keturunan China di Indonesia karena mereka mempunyai hambatan untuk menjadi Tentara. Selama kekuasaan Orde Baru relatif sulit ada ras keturunan China asli yang menjadi Tentara 
untuk ikut serta dalam usaha pembelaan Negara.

Pasal 31 (1): Tiap-tiap warga Negara berhak mendapat pengajaran, (2) pemerintah mengusahakan dan menyelenggarakan satu sistem pengajaran nasional, yang diatur dengan undang-undang.

Dalam kekuasaan era Orde Baru, jarang menemui ada ras keturunan China sekolah pada SD-SMA Negeri. Kebanyakan mereka sekolah di sekokal-sekolah swasta yang didirikan oleh komunitas mereka sendiri. Padahal setiap warga Negara termasuk di dalamnya ras keturunan China seharusnya berhak untuk mendapat pengajaran di sekolahsekolah Negeri yang dibiayai Negara.

Pasal 32: pemerintah memajukan kebudayaan nasional.

Selama Orde Baru, ras keturunan China juga belum mendapatkan haknya untuk memajukan kebudayaan mereka. Misalnya budaya barongsai yang menjadi salah satu wujud seni budaya ras keturunan China. Ada semacam stigma bahwa seni budaya dari ras keturunan China disamakan dengan seni budaya PKI yang oleh penguasa orde baru dijadikan musuh bersama yang harus diperangi. Jadi penguasa saat itu sibuk memerangi budaya seni yang dikait-kaitkan dengan PKI sehingga melupakan memerangi kemiskinan yang diderita rakyatnya.

Pasal 33 (1): Perekonomian disusun sebagai usaha bersama berdasar atas asas kekeluargaan, (2) Cabang-cabang produksi yang penting bagi Negara dan yang menguasai hajat hidup orang banyak dikuasai oleh Negara, (3) Bumi dan air dan kekayaan alam yang terkandung di dalamnya dikuasai oleh Negara dan dipergunakan untuk sebesar-besar kemakmuran rakyat.

Secara sepintas ras keturunan China memang diuntungkan dengan ketentuan Pasal 33 tersebut, sebab secara empiris tidak sedikit ras keturunan China yang menguasai cabang-cabang produksi yang penting. Mulai hak pengelolaan hutan, minyak bumi, tambang, listrik, produksi bahan pangan pokok, dimiliki dan dikelola ras keturunan China pada era Orde Baru.

Ketentuan Pasal 6, 26, 27, 28, 29, 30, 31, 32, 33 UUD 1945 (sebelum amandemen) merupakan bukti ketidakteraturan jaminan hak dan kewajiban warga Negara keturunan China di Indonesia secara konstitusional, sehingga pada era 
orde lama dan orde baru, ras keturunan China tidak mendapat jaminan hak dan kewajiban sebagai penyelenggara Negara baik dalam bidang eksekutif, legislatif dan yudikatif. Namun demikian, ras keturunan China diberi peluang yang luas untuk mengembangkan dirinya dalam bidang ekonomi. Dalam bidang ekonomi inilah Ras keturunan China mampu mengidentifikasi dirinya sehingga menjadi warga Negara yang keberadaannya harus diakui oleh negara. Sebenarnya dalam politik hukum, ras keturunan China yang eksis dalam bidang ekonomi memang sengaja "dimanfaatkan" oleh penyelenggara Negara, karena sejak dahulu ras keturunan China mempunyai kemampuan lebih dalam bidang ekonomi. Secara historis, nenek moyang mereka, pertama kali datang ke nusantara ini juga berdagang dan melakukan kegiatan di bidang ekonomi lainnya.

Keberhasilan ras keturunan China dalam bidang ekonomi dalam beberapa peristiwa mampu menjadi pemicu kecemburuan warga negara asli (Bumiputera), sehingga konflikkonflik horizontal antara ras keturunan China dengan ras keturunan asli Bumiputera hampir selalu disebabkan oleh ketimpangan ekonomi yang mengakibatkan ketidakadilan distribusi sumbersumber kemakmuran antara mereka. Kemudian Negara hadir melakukan represi untuk menyelesaikan konflik yang terjadi dengan dalih stabilitas. Disinilah hukum Negara semakin menegaskan dirinya dengan menciptakan problem ketidakteraturan hukum khususnya hubungan ras keturunan China dengan ras keturunan Asli Pribumi.

Beberapa ketentuan yang terkait dengan justifikasi ketidakteraturan hukum ras keturunan WNI China dalam UUD Negara RI Tahun 1945.

Pasal 6 :

(1) Calon Presiden dan calon Wakil Presiden harus seorang warga Negara Indonesia sejak kelahirannya dan tidak pernah menerima kewarganegaraan lain karena kehendaknya sendiri, tidak pernah mengkhianati Negara, serta mampu secara rohani dan jasmani untuk melaksanakan tugas dan kewajiban sebagai Presiden dan Wakil Presiden.

Ketentuan pasal 6 tersebut masih memberikan pembatasan bagi WNI untuk menjadi calon Presiden dan Calon Wakil Presiden. Pembatasan 
tersebut adalah dalam kata .... harus seorang warga Negara Indonesia sejak kelahirannya...berarti WNI pribumi maupun China yang lahir tidak menjadi WNI dan baru kemudian menjadi WNI, tidak dapat menjadi Calon Presiden dan Calon Wakil Presiden apalagi menjadi Presiden dan Wakil Presiden. Sekalipun tidak pernah mengkhianati Negara, mampu secara rohani dan jasmani untuk melaksanakan tugas dan kewaijban sebagai Presiden dan Wakil Presiden tidak cukup. Padahal kesadaran dan kemauan untuk menjadi Presiden dan Wakil Presiden harusnya tidak hanya diukur dari status WNI sejak kelahirannya saja, tetapi harus pula dilihat dari integritas moral, integritas intelektual dan integritas sosialnya.

Ketentuan pasal 26 tersebut juga masih memberikan justifikasi perbedaan WNI dengan asal usulnya. Perbedaan tersebut ada pada kata ..... orang-orang bangsa Indonesia asli dan orang-orang bangsa lain... masih ada kata asli dan bangsa lain. Kata asli menunjuk asal-usul pribumi sedangkan kata bangsa lain, menunjuk bukan pribumi, yakni bisa China atau bangsa lainnya selain pribumi. Dalam ketentuan pasal 26 tersebut juga membedakan kata warga Negara dengan penduduk. Kerumitan muncul ketika disebut penduduk. Sebab untuk diakui menjadi penduduk harus memenuhi syarat sebagaimana dalam UndangUndang Kewarganegaraan. Sementara, Undang-Undang Kewarganegaraan seringkali justru menjadi justifikasi persoalan kependudukan khususnya bagi WNI yang tidak asli.

Pasal 28 A : Setiap orang berhak untuk hidup serta berhak mempertahankan hidup dan kehidupannya.

Ketentuan pasal 28A ini memberikan jaminan bagi WNI China yakni berhak untuk mempertahankan hidup dan kehidupannya, mulai lahir sampai dengan meninggal di wilayah Negara Kesatuan RI. Mempertahankan hidup dapat dimaknai sebagai hak dalam bidang ekonomi (berusaha, berdagang dan lain-lain), sedangkan mempertahankan kehidupannya bermakna mempertahankan kualitas hidupnya. Kualitas hidup harus 
diukur secara materiil dan immaterial. Untuk ranah ini, WNI China di Indonesia secara umum relatif lebih baik dibandingkan dengan WNI pribumi. Mereka lebih menguasai dan memiliki cabang produksi yang menguasai hajat hidup orang banyak yang dijamin oleh hukum di bidang ekonomi.

Pasal 28 B :

(1) Setiap orang berhak membentuk keluarga dan melanjutkan keturunan melalui perkawinan yang sah.

(2) Setiap anak berhak atas kelangsungan hidup, tumbuh, dan berkembang serta berhak atas perlindungan dari kekerasan dan diskriminasi.

Legalitas perkawinan, untuk WNI China (dan WNI lain beragama Kristen) tunduk pada hukum perkawinan sebagaimana diatur dalam Buku Kedua Burgelijke Wet Boek (BW), sedangkan untuk WNI pribumi yang beragama Islam tunduk pada Undang-Undang Nomor 1 Tahun 1974 Tentang Perkawinan. Dengan hukum yang berbeda tersebut sebenarnya masih menegaskan justifikasi perbedaan di depan hukum bagi WNI China dalam membentuk keluarga dan melanjutkan keturunannya melalui perkawinan yang sah.
Merujuk pasal $28 \mathrm{C}$ dan $28 \mathrm{D}$, secara substansiil ketentuan pasal tersebut menjadi jaminan bagi hak WNI China. Hanya pada implementasi ketentuan tersebut dalam kenyataan masih menimbulkan berbagai persoalan konstitusional. Status kewarganegaraan seringkali masih menjadi polemik jaminan status kependudukan bagi WNI China.

Selanjutnya, ketentuan pasal 28 E secara substansiil sudah memadai untuk menjamin agama, pendidikan, pengajaran, memilih pekerjaan, memilih kewarganegaraan, memilih tempat tinggal (meninggalkan dan kembali), kebebasan meyakini kepercayaan khususnya bagi WNI China. Sebab konflik tentang keyakinan kepercayaan masih sering terjadi antara WNI pribumi dengan WNI China. Kelompok ekstrem aliran kepercayaan masih menjadi pemicu utama konflik kepercayaan dimaksud.

Pasal 28G:

(1) Setiap orang berhak atas perlindungan diri pribadi, keluarga, kehormatan, martabat, dan harta benda yang dibawah kekuasaannya, serta berhak atas rasa aman dan perlindungan dari ancaman ketakutan untuk berbuat atau tidak 
berbuat sesuatu yang merupakan hak asasi.

(2) Setiap orang berhak untuk bebas dari penyiksaan dan perlakuan yang merendahkan derajat martabat manusia dan berhak memperoleh suaka politik dari negara lain.

Kerusuhan dan kegaduhan politik di wilayah rakyat yang berakibat huru hara masal yang terjadi di kota-kota besar, seringkali masih memunculkan sentimen kesenjangan ekonomi. Seperti diketahui, aset perekonomian yang ada di kota-kota besar di Indonesia dimiliki atau dikuasai oleh WNI China. Pada saat kerusuhan terjadi, relatif para perusuh menjadikan aset milik WNI China sebagai obyek $\mathrm{j}$ yang harus dijarah. Entah sudah direncanakan atau belum, fakta menunjukkan setiap kerusuhan, WNI China merasa ketakutan untuk dijadikan sasaran amuk masa. Negara dan hukum yang hadir dalam bentuk Polisi, seringkali juga tidak mampu menjamin hak dan kebebasan WNI China atas perlindungan diri pribadi, keluarga, kehormatan, harkat, martabat, dan harta benda yang dibawah kekuasaannya, rasa aman, dan perlindungan dari ancaman ketakutan dari masa yang huru hara tersebut. Kasus perkosaan terhadap WNI China pada 1998 adalah potret penyiksaan dan perlakuan yang merendahkan derajat martabat manusia WNI China di Indonesia.

$$
\text { Ketentuan pasal } 28 \text { H,I,J }
$$
menjadi bukti jaminan konstitusional WNI China untuk sejahtera lahir batin secara bermartabat tanpa perlakuan diskriminatif dan kesewenang-wenangan pihak manapun. Dalam pasal tersebut dijelaskan setiap orang bebas dari diskriminasi, dan perlindungan terhadap HAM, serta menjaga dan menghormati hak dan kewajiban orang lain sesuai dengan ketetapan undang - undang.

Pasal 32 :

(1) Negara memajukan kebudayaan nasional Indonesia di tengah peradaban dunia dengan menjamin kebebasan masyarakat dalam memelihara dan mengembangkan nilai-nilai budayanya.

(2) Negara menghormati dan memelihara bahasa daerah sebagai kekayaan budaya nasional.

Ketentuan pasal 32 ini menjadi jaminan konstitusional bagi WNI China untuk memajukan kebudayaannya. Setelah reformasi tahun 1998, kebebasan WNI China dalam memelihara dan 
mengembangkan nilai-nilai budayanya relatif berjalan dengan baik. Bahkan beberapa bangunan masjid yang dibangun di Indonesia mulai mengadopsi gaya arsitek Tionghoa, ada pula yang diberi nama masjid Cheng Ho, nama seorang panglima perang China yang konon beragama Islam. Seni tari Barongsai, model baju Koko, konon juga mengadopsi model baju khas China, yang justru menjadi gaya pakaian umat Islam yang kemudian diberi nama baju Taqwa.

Pasal 33 ditambah dua ayat yakni ayat (4) dan ayat (5) :

Ayat (4) perekonomian nasional diselenggarakan berdasar atas demokrasi ekonomi dengan prinsip kebersamaa, efisiensi berkeadilan, berkelanjutan, berwawasan lingkungan, kemandirian, serta dengan menjaga keseimbangan kemajuan dan kesatuan ekonomi nasional.

Ayat (5) ketentuan lebih lanjut mengenai pelaksanaan pasal ini diatur dalam undang-undang.

Ketentuan pasal 33 tersebut disatu sisi menjadi peluang dan jaminan konstitusional bagi WNI China untuk memanfaatkan prinsip demokrasi ekonomi. Tetapi disisi lain, masih dicurigai oleh kelompok WNI pribumi, bahwa keberhasilan ekonomi WNI China yang diperoleh berdasarkan prinsip demokrasi ekonomi, 'dituduh' sebagai hasil Kolusi Korupsi dan Nepotisme. Adanya oknum pengusaha WNI China yang kebetulan bermasalah $(\mathrm{KKN})$, menjadi pembenar tuduhan tersebut.

Substansi perubahan setelah amandemen memang lebih baik dan lebih bisa menjamin keanekaragaman yang ada di Indonesia. Namun, semangat keanekaragaman yang terkandung dalam konstitusi hasil amandemen tersebut belum diikuti oleh perubahan peraturan perundangundangan sebagai pelaksanaan ketentuan tersebut. Tidak sinkronnya Konstitusi dengan peraturan perundang-undangan yang ada juga semakin menegaskan ketidakteraturan hukum di dalam mengatur ketertiban kehidupan bangsa dan negara. Hal ini dibuktikan dengan tidak sedikitnya gugatan judicial review UndangUndang yang diajukan oleh warga negara ke Mahkamah Konstitusi karena dianggap bertentangan dengan Konstitusi. 


\section{Justifikasi Problem Ketidakteraturan Hukum di Bidang Kependudukan dan Imigrasi Bagi Ras China di Indonesia}

Sebenarnya era kebebasan (keteraturan hukum) dimulai pada era Presiden Habibie (1998-1999), yakni kebebasan pers, kebebasan politik, kebebasan dalam budaya dan kebebasan kewarganegaraan. Referendum bagi propinsi Timor Timur, banyaknya partai politik, pers bebas, tahanan politik dibebaskan, semua ras keturunan dapat memasuki dunia politik, ketatanegaraan, adalah wujud kebebasan era Habibie. Kemudian dilanjutkan oleh era Gus Dur (Abdurrahman Wahid 20002002) dan kemudian era Megawati (2002-2004). Sejak saat itu, ras keturunan China menemukan momentumnya untuk mensejajarkan diri dengan ras keturunan lainnya sebagai WNI di Indonesia. Ada yang menjadi tentara, polisi, PNS, politisi, kepala daerah, menteri. Jadi pada era sekarang ini, WNI ras keturunan China di Indonesia secara yuridis sudah sama hak dan kewajibannya dengan WNI ras keturunan lainnya. Namun, persoalan seringkali muncul terkait dengan penegakan hukum terkait dengan ras keturunan China khususnya kewarganegaraan dan imigrasi. Secara yuridis normatif, ras keturunan China dijamin Konstitusi dan hukum yang berlaku, tetapi secara empiris masih dipersulit untuk mendapatkan jaminan hak dan kewajibannya.

Problem Ketidakteraturan hukum terkait dengan Kewarganegaraan dan Keimigrasian ras keturunan China secara historis, terdapat dalam peraturan perundangundangan sebagai berikut :

\section{a) Undang-Undang Nomor 3 Tahun 1945 Tentang Kewarganegaraan.}

Dalam Undang-Undang Nomor 3 Tahun 1945 ini, yang dimaksud dengan penduduk Negara ialah mereka yang bertempat tinggal di Indonesia selama satu tahun berturutturut. Selanjutnya, yang menjadi warga Negara Indonesia pada pokoknya : 1) penduduk asli dalam daerah RI, termasuk anak-anak dari penduduk asli tersebut; 2) istri seorang WNI; 3) keturunan dari seorang warga negara yang kawin dengan wanita WNA; 4) anak-anak yang lahir dalam daerah RI yang oleh orang tuanya tidak diakui dengan 
cara yang sah; 5) anak-anak yang lahir dalam daerah Indonesia dan tidak diketahui siapa orang tuanya; 6) anak-anak yang lahir dalam waktu 300 hari setelah ayahnya, yang mempunyai kewarganegaraan Indonesia, meninggal; 7) orang bukan penduduk asli yang paling akhir telah bertempat tinggal di Indonesia selama 5 tahun berturutturut, dan telah berumur 21 tahun atau telah kawin. Dalam hal ini tidak berkeberatan untuk menjadi WNI, ia boleh menolak dengan keterangan, bahwa ia adalah warga Negara dari Negara lain; 8) masuk menjadi WNI dengan jalan pewarganegaraan (naturalisasi).

Berdasarkan ketentuan tersebut jelas masih belum menjamin keberadaan ras keturunan China. Sebab ras keturunan China baru dapat menjadi WNI apabila menjadi istri WNI asli. Katagorisasi asli tidak asli masih nampak dalam Undangundang tersebut.

\section{b) Undang-Undang Nomor 62 Tahun 1958 Tentang Kewarganegaraan.}

Dalam Undang-undang ini, yang dimaksud dengan warganegara adalah setiap orang yang menurut
Undang-undang Kewarganegaraan adalah termasuk warganegara, sedangkan orang asing ialah orang yang bukan warganegara. Yakni mereka yang telah menjadi warga Negara berdasarkan Undangundang/Peraturan/ Perjanjian yang terlebih dahulu berlaku (berlaku surut) dan mereka yang memenuhi syarat-syarat tertentu yang ditetapkan dalam UU ini. Dengan ketentuan demikian berarti Undang-undang ini tidak jauh beda dengan UU sebelumnya. Artinya masih membedakan keaslian dan tidak asli. Bagi ras keturunan China menurut Undang-undang tersebut masih belum sepenuhnya diakui sebagai warga Negara Indonesia asli tetapi warga Negara Indonesia keturunan. Cap WNI keturunan ini sampai sekarang masih melekat dalam ras keturunan China di Indonesia.

\section{c) Undang Undang Nomor 12 Tahun 2006 Tentang Kewarganegaraan.}

Tujuan pokok dibuatnya Undang-undang ini adalah untuk menjamin potensi, harkat, dan martabat setiap orang sesuai dengan hak asasi manusia. Ketentuan tentang warga Negara diatur dalam pasal 2. 
Dalam pasal 4 dijelaskan mengenai orang yang masuk dalam kategori WNI, dimana pada huruf (1) pasal tersebut menjelaskan Indonesia menganut Ius Sanguinis.

Kemudian ketentuan pasal 5 :

(1) Anak WNI yang lahir di luar perkawinan yang sah, belum berusia 18 (delapan belas) tahun dan belum kawin diakui secara sah oleh ayahnya yang berkewarganegaraan asing tetap diakui sebagai WNI.

(2) Anak WNI yang belum berusia 5 (lima) tahun diangkat secara sah sebagai anak oleh WNA berdasarkan penetapan pengadilan tetap diakui sebagai WNI.

Perincian tentang siapa yang menjadi WNI sebagaimana ketentuan pasal 4 dan 5 tersebut tidak mampu menghapus penegasan bahwa masih ada pembedaan WNI asli dan tidak asli sebagaimana ketentuan pasal 2 . Pemberian "cap" asli dan tidak asli kerap menimbulkan persoalan pengurusan dokumen kewarganegaraan dalam praktek. Surat Bukti Kewarganegaraan Republik Indonesia (SKBRI) bagi warga ras China masih menyisakan masalah khususnya apabila dikaitkan dengan pengurusan kependudukan dan keimigrasian. Meski pada pemerintahan BJ Habibie, SKBRI telah dihapus, namun fakta di lapangan masih mewajibkan dokumen SKBRI sebagai salah satu syarat. Namun, Pemerintah membantah bahwa masih ada permasalahan SKBRI tersebut, sebagaimana bantahan Kementerian Hukum dan HAM. Menurut Pemerintah, SKBRI hanya diperlukan bagi WNA yang mengajukan naturalisasi menjadi WNI sebagai dasar Keputusan Presiden untuk menyetujuinya.

\section{d) Undang Undang Nomor 23 Tahun 2006 Tentang Administrasi Kependudukan.}

Undang-undang ini dibuat bertujuan untuk memberikan perlindungan dan pengakuan terhadap penentuan status pribadi dan status hukum atas setiap peristiwa kependudukan dan peristiwa penting yang dialami oleh penduduk Indonesia yang berada di dalam dan/atau di luar wilayah NKRI. Dalam ketentuan pasal 2, dinyatakan bahwa :

Mendapatkan dokumen kependudukan dan seterusnya adalah hak setiap penduduk. Oleh karena hak setiap penduduk maka sudah seharusnya juga menjadi kewajiban Negara untuk memberikannya. 
Namun, di dalam kenyataan berbagai kesulitan masih dirasakan oleh WNI China yang akan mengurus dokumen kependudukan. Misalnya, bagi WNI China yang akan mengurus KTP tetapi agama yang dianut adalah Khonghucu, penyelenggara Negara di lapangan belum mau memasukkan ke dalam KTP bahwa agamanya adalah Khonghucu. Persoalan mencantumkan agama Konghucu dalam KTP menjadi masalah krusial, sehingga ras China sampai hari ini agar urusan KTP selesai terpaksa masih mengakui beragama Islam, Budha, Hindu, Kristen.

\section{e) Undang Undang Nomor 40 Tahun 2008 Tentang Penghapusan Diskriminasi Ras dan Etnis}

Tujuan utama dibuatnya undangundang ini untuk menegaskan bahwa diksriminasi ras dan etnis dalam kehidupan bermasyarakat merupakan hambatan bagi hubungan kekeluargaan, persaudaraan, persahabatan, perdamaian, keserasian, keamanan, dan kehidupan bermata pencaharian di antara warga Negara yang pada dasarnya selalu hidup berdampingan.
Dalam ketentuan pasal 1 angka 5, dinyatakan bahwa :

Yang dimaksud dengan tindakan diskriminasi ras dan etnis adalah perbuatan yang berkenaan dengan segala bentuk pembedaan, pengecualian, pembatasan, atau pemilihan berdasarkan pada ras dan etnis, yang mengakibatkan pencabutan atau pengurangan pengakuan, perolehan, atau pelaksanaan hak asasi manusia dan kebebasan dasar dalam suatu kesetaraan di bidang sipil, politik, ekonomi, sosial, dan budaya.

Dalam kenyataan masih ditemukan perlakuan diskriminasi terhadap WNI ras dan etnis China untuk mendapatkan pendidikan agama dalam sekolah-sekolah formal. Berdasarkan pada Peraturan Menteri Agama Nomor 10 Tahun 2010 tentang Struktur Organisasi dan Tata Kerja Kementrian Agama, dan Peraturan Pemerintah Nomor 55 tahun 2007 tentang Pendidikan Agama dan Keagamaan, bahwa pelayanan pendidikan agama harus diberikan secara proporsional kepada umatnya. Namun, dalam kenyataan untuk pelayanan pendidikan kepada WNI China yang beragama Konghucu belum diberikan secara proporsional karena alasan pendidik dalam bidang agama Khonghucu masih sulit didapatkan. Menurut 
Perwalian Majelis Tinggi Agama

Konghucu (Matakin di Persatuan

Kerukunan Umat Beragama), menyatakan bahwa lembaga yang mencetak Pendidik Agama Konghucu sudah ada tetapi masih bersifat nonformal (seperti Pesantren di kalangan Islam), yakni di Solo bermana Sekolah Tinggi Agama Konghucu (STAK). Namun, perhatian pemerintah untuk memberikan status pengakuan STAK tersebut belum Nampak, padahal dalam Konstitusi dan Undangundang, hak untuk mendapatkan pengajaran pendidikan agama dijamin.

Masyarakat majemuk merupakan masyarakat yang rentan dengan konflik - konflik sosial. Kecenderungan yang demikian sangat tergantung dari pemahaman dan pengelolaan konflik dari penguasa negara, termasuk penguasa daerah. Berkitan dengan keberadaan kolektivitas Tionghoa, Geertz menekankan bahwa lebih dari golongan yang lain, adalah golongan Tiongha yang bersifat eksklusif ditilik segi agama, tempat tinggal, dan pelapisan sosial (Nurhadiantomo, 2004:35).
Konfigurasi pemisahan pribumi dan non pribumi menimbulkan kesenjangan sosial berujung konflik di negeri ini, yang tidak kunjung terselesaikan.

\section{Simpulan}

Di Indonesia pengaturan tentang WNI ras dan etnis China (khususnya) sudah dijamin dalam UUD Negara RI Tahun 1945 dan peraturan perundang-undangan organik yang ada. Namun, secara substansiil pengaturan dalam UUD Negara RI Tahun 1945 dan peraturan perundang-undangan organik tersebut masih menimbulkan perdebatan dan multitafsir. Antara ketentuan satu dengan yang lainnya masih saling bertentangan yang menjadi penyebab problem konstitusional ketidakteraturan hukum yang mengatur jaminan hak dan kewajiban bagi WNI ras dan etnis China secara sejajar dengan WNI asli.

Pembedaan WNI asli dan tidak asli menjadi bukti problem ketidakteraturan hukum yang menjustifikasi rasisme di Indonesia. Hal ini mengakibatkan perbedaan perlakuan dari penyelenggara Negara 
terhadap WNI tidak asli dari ras dan etnis China dalam bidang sosial, budaya, agama, kependudukan dan keimigrasian.

Problem-problem konstitusional dan peraturan perundangan yang seringkali berbeda secara diametral dengan problem doktrin, budaya, ekonomi, politik, sosial tersebut, masih meneguhkan dan menegaskan justifikasi sulitnya membela etnis China, sebagai WNI dalam bingkai Bhinneka Tunggal Ika di Indonesia.

\section{Rekomendasi}

Peraturan Perundang undangan harus selaras dengan Konstitusi. Dalam perumusan pasal dan aturan harus meminimalisasi multitafsir yang pada akhirnya menimbulkan konflik horizontal maupun vertikal. Perlindungan terhadap hak-hak warna negara yang sudah dijamin oleh Konstitusi harus diupayakan secara maksimal dengan melihat secara menyeluruh problemproblem doktrin, budaya, ekonomi, politik, sosial yang berkembang di masyarakat.

\section{Daftar Pustaka}

\section{Buku}

Furnivall,J.S., 1959, Colonial Policy and Practice: A comparative study of Burma and Netherlande Indie, New York : University Press.

Fuady, Munir, 2009, Sejarah Hukum, Bogor: Ghalia Indonesia.

Gilissen,John dan Frits Gorle, 2007, Sejarah Hukum, Bandung: Refika Aditama.

Nurhadiantomo, 2004, Konflik Konfik Sosial Pri dan Non Pri, Hukum Keadilan Sosial, Surakarta : Muhammadiyah University Press

Soe Hok Gie, 1997, Orang-Orang Di Persimpangan Kiri Jalan, Yogyakarta: Bentang Budaya.

Syamsudin, Nazarudin, 1993, Soekarno Pemikiran Politik dan Kenyataan Praktek, Jakarta : Raja Grafindo Persada.

Wahidin, Syamsul, 2011, Konseptualisasi dan Perjalanan Dewan Perwakilan Rakyat Republik Indonesia, Yogyakarta: Pustaka Pelajar.

Mangunwijaya,YB. 1995. Gerundelan Orang Republik. Yogyakarta. Pustaka Pelajar. 


\section{Media Massa}

Jawa Pos. 3 Pebruari 2011

Jawa Pos. 4 Pebruari 2011 